\title{
Basic Economic Liberties: John Rawls and Adam Smith Reconciled
}

\author{
Nick Cowen, University of Lincoln ${ }^{1}$
}

\begin{abstract}
The moral status of economic liberty is a critical point of contention within liberal theory. Classical liberals, including Tomasi, suggest that economic activity is fundamental for exercising personal autonomy and its protection to be to the overall benefit of all persons. By contrast, egalitarian liberals, following Rawls, argue that economic activity is not a sufficiently significant site of moral development. Drawing on contemporary interpretations of Adam Smith, I argue that commercial practices cultivate attitudes of mutual trust and respect in a way that is unique and necessary for developing the moral powers. Although they need not be universally exercised, basic economic liberties must be available to all. While rejecting laissez-faire, this case suggests that well-ordered societies must protect a substantial degree of commercial activity as part of the basic structure.
\end{abstract}

Key words: liberalism, markets, Rawls, Adam Smith, moral powers, economic liberty

\footnotetext{
${ }^{1}$ Thanks are due to Charles Delmotte, Aris Trantidis, Maria Pia Paganelli, Mario Rizzo, Malte Dold, Richard Epstein, Samuel Estreicher, Brian Kogelmann and Jessica Flanagan for help with drafting this paper. I am also grateful for a great deal of supportive feedback received at conferences of the Association for Social and Political Philosophy, the Midwest Political Science Association, the Southern Political Science Association, the International Adam Smith Society, MANCEPT and the Britain and Ireland and Association for Political Thought.
} 
Are liberties to own productive property and engage in voluntary exchange basic in Rawlsian terms? This is a key controversy between classical liberals, such as Gaus (2010) and Tomasi (2012a) who affirm economic liberty to be essential rights within a public justificatory framework, and egalitarian liberals such as Freeman (2001), Rawls (1975; 1999) and Stilz (2014), who do not. So far, proponents have relied on the wealth-generating properties of markets and the supposed greater personal autonomy that economic freedom permits. These arguments have not convinced Rawlsians who suggest they do not show how economic liberty is necessary for developing citizens' moral powers. This article attempts to reconcile what Hardin $(2003,41)$ identifies as two distinct traditions that have so far resisted combination: political liberalism and economic liberalism.

My point of departure is that both sides in this debate currently rely on a shared neoclassical conception of economic activity. In doing so, they miss some insights from the classical political economy tradition that suggest that commerce exerts a critical influence on the moral character of society (Hirschman 1982). Although cognizant of the vices associated with business as well, scholars in this tradition recognize the often morally improving character of commercial institutions. Montesquieu (1777, XX.2) claims that commerce encourages peace and curbs prejudice between nations. Domestic commercial norms are a more mixed blessing, encouraging a sense of exact justice, that is norms against predation but also against support and sympathy among friends. Hume (1994a) believes there to be an unbreakable link between 'industry, knowledge, and humanity' and argues that commerce among diverse nations can make everyone industrious and prosperous through mutual gains (1994b). Kant $(1795,149)$ describes commerce as how 'peoples would be at first brought into peaceful relation with one another, and 
so come to an understanding and the enjoyment of friendly intercourse, even with their most distant neighbours.'

In this article, I focus on reconciling Adam Smith (1981; 1982), who makes an important contribution to this moral tradition, with Rawls. Rawls $(1999,161)$ uses a proto-utilitarian representation of Hume and Smith as a foil for his contractarian account of justice as fairness. Contemporary scholars, including Schliesser (2017), McCloskey (2007) and Paganelli (2017; 2010), have recovered a more socially oriented interpretation of Smith that suggest he was more than a proto-utilitarian when it came to the social role of economic activity, making this an opportunity to address Rawls' characterization. Smith is a useful exponent in this context because of his greater optimism about the possibility of respecting social equality between persons compared to Hume (Levy and Peart 2004; Debes 2012). It is timely to explore these ideas as part of the discussion of basic institutions in a way that aligns with Rawls' method of 'wide reflective equilibrium' where theoretical principles and moral judgements are refined with the support of background social theories (Daniels 1979).

With the recovery of this classical economic tradition in mind, I argue for considering economic liberties to be basic because of the unique role that commerce plays in developing citizens' sense of justice which requires them to view one another as equals with their separate ends and yet capable of engaging in beneficial mutual cooperation. Rawls associates economic liberty with more narrowly expedient concerns with efficiency and material welfare. A classical political economy account suggests that engaging in commerce induces creative thinking and critical reflection about one's reasoning and ends, as well as the ends and reasoning of others. I show how this commercial activity requires thick basic economic liberties. I argue that democratically constituted firms and public sector organizations contribute to economic 
cooperation. However, they cannot replace private enterprise as various socialist proposals suggest without the state exercising direct control over firm membership in a way that prevents citizens from gaining experience of governance under voluntary conditions. In the concluding, section I explain how the Rawlsian approach to protecting basic liberties, in general, can help establish what legitimate regulation of economic liberty could look like.

This argument has different normative implications to some existing accounts of basic economic liberties. Tomasi $(2012 \mathrm{~b}, 33)$ affirms a thick conception of economic liberty as part of his preferred regime of market democracy, and further associates it with the individualist orientation of the United States. By contrast, egalitarian liberals see the United States as deviating substantially from any plausible notion of justice as fairness. They endorse Rawls' proposed theoretical alternatives to capitalism, liberal socialism and property-owning democracy (O'Neill 2017). When looking at real-world examples, egalitarian liberals point to successful welfare-state regimes such as Sweden and Denmark. However, all these regimes protect a substantial degree of individual economic freedom alongside supportive welfare systems (Bergh 2020). Indeed, according to inevitably rough measures of economic freedom, the United States is less free than some social democracies (Sumner 2015, 61). So, my argument is a defense neither of a rightwing Rawlsianism nor of American capitalism against other forms of capitalism but a more general defense of the centrality of commerce. I argue that substantive economic liberty is a fundamental, rather than contingent, feature of liberal societies broadly construed albeit, as with all liberties, often inadequately and unevenly realized. While this is a theoretical argument, it has implications for critiquing emerging authoritarian alternatives to liberal democratic regimes, such as in China, that deploy market practices on an expedient basis to pursue growth while simultaneously denying both fundamental civil and economic liberties to citizens. 


\section{The question of basic economic liberties}

Giving priority to a set of basic liberties when establishing fair institutions is a core feature of Rawls' theory of justice. The priority of liberty is key to Rawls distinguishing his theory from utilitarian alternatives:

Justice denies that the loss of freedom for some is made right by a greater good shared by others. The reasoning which balances the gains and losses of different persons as if they were one person is excluded. Therefore in a just society the basic liberties are taken for granted and the rights secured by justice are not subject to political bargaining... (Rawls 1999, 28)

In Political Liberalism, Rawls links basic liberties to the development of citizens' two moral powers, the capacity for a sense of justice and conception of the good (Rawls 2005, 29495). Basic liberties are supposed to be fully adequate to facilitate and protect a range of practices that cultivate these moral powers. These are freedom of thought, liberty of conscience; political liberties and freedom of association; liberty and integrity of the person and rights covered under the rule of law. However, Rawls excludes economic liberties from such priority: 'the right to own certain kinds of property (e.g., means of production) and freedom of contract as understood by the doctrine of laissez-faire are not basic' (Rawls 1999, 54). This position relates to domestic economic arrangements but Rawls was also skeptical of the value of international free trade for the pursuit of world peace and stability (Rawls and Van Parijs 2003).

Tomasi makes a Rawls-inspired substantive moral case for endorsing a set of 'thick' economic liberties as 'among the basic rights of liberal citizens' (Tomasi 2012a, 81). He argues that decisions such as starting a business, entering a voluntary labor contract, or saving for retirement, can make up important parts of an individual's life plan. This makes economic 
liberties a basis for 'responsible self-authorship', and thus constitutes a similar justification that egalitarian liberals espouse for personal liberties (Tomasi 2012a, 95). Tomasi's egalitarian critics acknowledge the potential for self-authorship in economic decision-making, but only in a narrow set of cases. Key points of contention are over the importance of economic liberties to people's life plans, their potential compatibility with the other basic liberties and the compatibility of participation in markets with self-respect (Stilz 2014).

So far, the classical liberal case for basic economic freedoms falls short of the requirements of a Rawlsian justification for basic liberties (Platz 2014). On the other hand, the liberal egalitarian case for rejecting basic economic liberties has its own weaknesses because it seems capable of being applied to a range of civil liberties that are usually taken to be basic (Brennan 2019). This leads Flanigan (2018) to suggest that all liberties, no matter how seemingly trivial, are basic, potentially deflating attempts to prioritize a specific range of liberties.

Nevertheless, a more precise focus on the adequate conditions of the development of the moral powers suggests a unique role for a relatively 'thick' conception of economic liberty.

\section{Sites of moral cultivation}

What does a person need to cultivate their moral powers? For Rawls, citizens of a liberal society need to be rational and reasonable. They must be rational in the sense of being able to weigh up conflicting values to produce a conception of the good and develop a coherent life plan (Rawls 2005, 51). They must be reasonable in the sense of recognising other people's interests as independently valuable, their own fallibility, and that other people will necessarily come to different conclusions about their own conception of the good, and some disagreement about the content of justice (Rawls 2005, 53-54). This is what allows a political community to govern through public reason and maintain an overlapping consensus based on reasonable pluralism. 
In terms of sites where these powers are cultivated, Rawls has in mind associations such as families, colleges, religious groups and clubs, as well as formal political institutions (Rawls 1999, 186; 2005, 220). These make up the 'background culture' formed from the social practices that basic liberties protect. However, there is something missing from Rawls' framework. The set of protected practices are orientated around thick values and interests. The resulting associations are predictably going to be segregated along lines of shared comprehensive moral doctrines. As a result, individuals are unlikely, through these practices alone, to become adequately familiar with the diversity of values in a community. Without such exposure, they will lack assurance of the rationality and reasonableness of citizens that engage in different private and civil practices to their own. They, in turn, may seem unreasonable to others with different conceptions of the good. Yet it is paradigmatic of a well-ordered liberal society that people with a wide range of values nevertheless see each other as fellow citizens, worthy of the same respect as themselves and their close associates.

An exception is the public sphere where everyone has a protected right to participate and the fair value of all social interests are supposed to be represented. The problem is that absent continuous experience of reasonable pluralism, this sphere is likely to take on an alien and polarized quality (Cf. Vallier 2019a). Values and attitudes absent from citizens' experience in civil society become sources of existential conflict and mistrust within political and administrative processes with no countervailing social background to assure people with differences of opinion of their reasonableness and overall shared interests as citizens. People will mistrust the sincerity of each other's arguments advanced in terms of public reason. The range of disagreement, even within political parties, may often be too broad for such citizens to recognize each other as reasonable. In this context, the political liberties alone are unlikely to be fully 
adequate for facilitating the cultivation of the moral powers. The solution to this weakness is including commercial practices as part of the social background. Participation in productive economic activities contributes to making citizens more capable of appropriately weighing the claims and interests of fellow citizens against their own.

Why has this contribution of economic activity been overlooked so far? For Rawls, excluding economic liberties from the list of basic liberties follows relatively straightforwardly from rejecting utilitarianism as an adequate theory of justice (Cf. Freeman 2011, 25). Under neoclassical economic assumptions, which Rawls takes as his point of departure when discussing political economy, economic decisions are a technical task of calculating an optimal plan from given resources and given ends to produce the best outcomes, a process whose precise advantage is that it does not require engagement with moral concerns (Rawls 1999, 248). However, the result is that Rawls' $(1999,240)$ description of economic activity is curiously agentless and static:

[C]ompetitive prices select the goods to be produced and allocate resources to their production in such a manner that there is no way to improve upon either the choice of productive methods by firms, or the distribution of goods that arises from the purchases of households.

Economic judgement, on this account, corresponds, at best, to prudence and sound bookkeeping, just following price signals wherever they point (McCloskey 2011). Practicing these sorts of judgements could plausibly contribute to people's capacity for rational calculation and to defer gratification, useful for many coherent life plans. Rawls certainly acknowledges the expediency of market activity to achieve many justified social ends $(1999,245)$ and for positive steps to make and keep market competitive (2001a, 141). However, on his account, economic 
activity does not contribute directly to the moral powers; at least, not in a way not equally achievable through appropriate upbringing and having to exercise patience as part of any serious practice. Although this stylized view of the economy is useful for some purposes of clarification in economic theory, Rawls' reliance on this view rules out conceiving economic liberty to be a site of moral development. Drawing on Smith's understanding of commercial society, I now show how this contribution is critical.

\section{The Smithian role of commerce in moral cultivation}

How does a Smithian account of commercial society depart from Rawls' understanding of economic activity? Smith is well-known for his contribution to economic thought but he was principally a moral philosopher (McCloskey 2008). Yet during the $19^{\text {th }}$ and much of the $20^{\text {th }}$ centuries, both Smith's critics and sympathetic interpreters tended to read his moral theory independently from, or even in contrast to, his contributions to economics (Tribe 2008). His central lesson was taken to be that self-interested people could, through voluntary exchange and the division of labor, end up unintentionally benefitting each other. This interpretive lens made sense when economic theory was pre-occupied with formalizing the efficiency properties of market exchange (Boettke 1997, 20). For example, Samuelson's description of the classical canon suggests that Smith was grasping primitively towards intuitions that could later be codified successfully in mathematical models (Samuelson 1978). This misses the side of Smith's account that considers the way that commerce interacts with political processes and wider civil society.

Rather than a conception of humanity as purely rationally self-interested, at the heart of Smith's moral theory is a conception of persons as admittedly partial to their own interests but socially oriented and sensitive to the approval of others (Smith 1982 III.2.1). We gain pleasure 
out of achieving 'mutual sympathy' and harmonizing our sentiments with others; we are upset when our sentiments are out of alignment with those of our friends and company (Smith 1982 I.2.1). Critically, people generally desire not so much to have the approval of others but to be, in fact, worthy of their approval (Smith 1982 III.2.7). This is what prompts people's motivations to act morally. Yet our natural sentiments, drawn from our embodied sensations, cannot be shared directly between people (Smith 1982 I.1.2). So they are vulnerable to distortions (Smith 1982 III.4.3). They lead us to overweight our interests, for example, to assume that a trivial personal loss is the equivalent of a distant national catastrophe (Smith 1982 III.3.4). The sentimental gaze often leads the public to be more pre-occupied with the fate of the rich and famous than the poor and disadvantaged (Smith 1982 III.2.7).

How are these moral sentiments refined? Actions and attitudes based on gross misjudgments attract opprobrium, to different degrees and implications, from close friends, associates or strangers. For example, Smith suggests that individuals caught up in a low mood should seek out wider company that will take them out of themselves and make them acknowledge the relative triviality of their concerns (Smith 1982 III.3.39). We often benefit from friends chiding us not to be so focused on ourselves. Amongst strangers, we are even more encouraged to exercise self-command and distance from our inward emotions.

Our moral development, therefore, is an increasingly fine-tuned contextual reconciliation of our personal judgements with that of the rest of society and, ultimately, humanity (Smith 1982 III.4.8). Smith uses a metaphorical figure, the impartial spectator, to describe the psychological mechanism that individuals, through both instruction and experience, use to become more familiar with and guided by more remote, generalizable sentiments and sympathies (Smith 1982 III.1.6). Awareness of the impartial spectator and its representative, 'the ideal man within the 
breast', has the consequence of prompting us to act appropriately to gain public approval (Smith 1982 III.4.4; 1982 VI.i.11). It also forms the basis of our internal motivations to behave, in the ideal, in a more 'wise and virtuous' (Smith 1982 VI.ii.3.3) way even when there is no direct reward in terms of public approval. This distinction, between our untutored inclination to selflove and our capacity to view ourselves from an impartial distance, parallels Rawls' distinction between mere rationality on the one hand, and reasonableness on the other, the capacity to recognize our own interests as having ultimately the same weight as our fellow citizens.

The strength of this public-spirited motivation is sensitive to context and socialization. For example, a classic arena where the impartial spectator is easily silenced is in the discussion of foreign policy and war, where a nation's enemies are remote, easily caricatured and dehumanized, making it easier for public sentiment to see only one side in a dispute (Smith 1982 III.3.42). People with more opportunities to cultivate and prompt the intuitions of the impartial spectator ultimately conduct themselves in more humane and just ways. Family upbringing and schooling, where children first play and converse with people outside their intimate circle, are important stages in this moral development (Smith 1982 III.3.20).

There is a unique contribution from interaction with strangers that commercial exchange encourages. On the one hand, we are typically indifferent to the fortune of anyone whose interests are unrelated to our own and to whom we are under no particular duty to aid (Smith 1982 III.3.7). On the other hand, if we find ourselves in a position where the welfare of others is specifically dependent on us, then propriety prompts us to act and, especially, to avoid harm (Smith 1982 III.3.5). What commercial exchange does is make us temporarily responsible for a great many strangers, and us in turn dependent on a multitude of strangers throughout our daily lives. With each other's interests aligned (both our successes and failures will be publicly judged 
in some form or another), we become habituated to taking the needs of the stranger that we generally come across seriously. Commerce also contributes to a sense of fellow feeling among those obliged to engage in more intimate forms of cooperation: 'Colleagues in office, partners in trade, call one another brothers; and frequently feel towards one another as if they really were so' (Smith 1982 VI.2.1). As a result, "even the ordinary commerce of the world is capable of adjusting our active principles to some degree of propriety' (Smith 1982 III.3.5). So, Smith sees business as part of this wider framework of socialization. It is a midpoint between the deep but partial sympathies that friends and family share and the otherwise cold, remoteness of humanity in the abstract. As Paganelli $(2017,463)$ argues, Smith recognizes a dignity and equality in mutual exchange relationships often absent in other social interactions:

Using our imagination to place ourselves in a neutral and distant position from ourselves helps us see our egocentrism and humbles us into reconsidering ourselves as just one in a multitude. This also help us see others as worthy of respectful interactions: if the other is just like me, one in a multitude, I do not need to use violence or to fawn like a puppy to get my dinner from him. I can simply persuade him to exchange with me.

In the Wealth of Nations, Smith aims to explain the role of commerce in material improvement rather than morality as such. Nevertheless, stated views complement, rather than contradict, his framework in Moral Sentiments. He writes 'Commerce... ought naturally to be, among nations, as among individuals, a bond of union and friendship' in the context of opposing mercantilist trade policies (Smith 1981 IV.iii.C.9). In addition, Smith discusses how the promulgation of commercial relations helps equalize people's political status. He narrates the decline of feudal social arrangements where productive surpluses are appropriated by aristocratic lords and then distributed through displays of largesse like public feasts to subordinates (Herzog 2014, 710). 
This is how people are maintained as political dependents. As Smith describes, commerce eats away at these arrangements by expanding the availability of luxury goods that rich aristocrats can consume. This tempts them into selling off rights to their land in return for mere 'trinkets and baubles' (Smith 1981 III.iv.15). Thus commerce, without intentional design, undermines traditional relations of patronage, giving ordinary workers and traders a substantial degree of social independence.

In another case, Smith examines the malign consequences of England's poor laws that tie impoverished laborers to their home parishes (Smith 1981 I.x.c.45; cf. Wolf 2017).

Geographically confining those dependent on poor relief was seen as the only way to provide for them while discouraging them from exploiting the system and preventing parishes from shifting their social obligations on to other districts. Smith instead supported labor mobility, partly for familiar reasons of what we now call economic efficiency: mobile laborers can travel to where their work is more in demand, raising average wages and productivity. But more significantly for Smith, keeping individuals tied to local parishes forcibly reduced them to dependency. This disfigured relations with other local inhabitants and thus reduced the basis for mutual respect.

In these cases, Smith (1981 VI.ix.51) points out the beneficial consequences of 'the obvious and simple system of natural liberty' over alternatives. In addition, the distributive outcomes are achieved through procedures that are consistent with liberty and involve treating people as mutual co-operators rather than subordinates and superiors, or dependents and benefactors. Smith's case thus resonates with Rawls' notion of perfect procedural justice: it achieves a morally compelling material outcome and does so through a fair (or, at least, fairer) procedure. For neither Rawls nor Smith is the value of the social institution only in the material 
outcome it produces (although it figures in the overall evaluation). It is what participation in that institution represents in terms of moral status and social distinction.

Smith was under no illusion that economic activity alone could be relied on to cultivate the appropriate moral capacities, especially when taken to exclusion of all other activities. He feared that monotonous routine labor, in particular, could numb and distort the sentiments of factory workers; and that merchants could develop too close sympathies with each other and conspire to raise prices (Smith 1981 V.i.f.50; 1981 I.X.C.27). He was thus a supporter of subsidizing primary education (Smith 1981 V.i.f.54) and drew attention to the role of philosophy, as well as public diversions such as theatre, as additional sources of moral refinement and reflection (Smith 1981 V.i.g.15). Nevertheless, he saw commerce as making a distinct contribution to expanding sympathy across society. Having recovered this general account of how commercial activity facilitates moral improvement, I set out how these activities relate specifically to the sense of justice as a moral power.

\section{A sense of justice}

Both Smith and Rawls begin with the presumption that people are motivated to act in a just manner but have neither the natural capacity to know what the content of justice is nor a willingness to trust that others will follow it. A key role of social institutions for both theorists is to develop in people the capacity for a sense of justice and establish stable expectations that others will generally follow its requirements. Their point of division is with respect to the role of economic activity which Rawls takes to be irrelevant to moral cultivation. As I have indicated above, Rawls' position on economic activity reflects neoclassical premises that tend to view economic decisions as one of calculating where to allocate resources. Under such assumptions, 
there is little space (or necessity) for humane reflection or judgement about the interests of oneself and other people.

This is where the Smithian account departs from Rawls. Participation in commercial decision-making and bargaining in a competitive market (that is, with people who have both the right and capacity to walk away from an unsatisfactory agreement) engages and exercises moral deliberation. Commercial activity makes people responsible for satisfying the interests of others, while also subjecting them to responsive feedback in terms of approval, disapproval, and at some margin refusal to cooperate altogether. This makes it a critical mechanism for developing a sense of what fairness is within one's community, and from that a more generalizable sense of justice applicable to the social background as a whole.

Rather than being just a technical task, successful bargaining requires an ability to reflect on one's own personal and business priorities; articulate them in the light of the various offers that other people make, and ultimately persuade others of the fairness and reasonableness of one's positions. Negotiation and management require anticipation of the needs and interests of others, and creative reflection and deliberation about how they can best be satisfied. Indeed, the drawing up of contracts and agreeing policies within and between firms is itself an exercise in governance at a limited scale. To be successful in the long run in a competitive market, such schemes must be acceptable to all parties involved. Thus a collective understanding of what constitutes fair agreement emerges from the trial and error of repeated attempts to establish complex private ventures with others.

Experience with achieving consensus in this setting helps people understand the nature of reasonable disagreement when it comes to making compromises in the public sphere. This is critical because the allocation of primary goods within a political community cannot itself be 
achieved through voluntary consent. Otherwise, political associations could be conceptualized as a form of private association. This means that citizens, in order to evaluate the justice of a political order, need a good practical idea of the social arrangements other citizens would publicly endorse. It is through participation in bargaining and contracting in civil society that citizens discover how to deliberate effectively about what generally constitutes legitimate decision processes and reasonable demands to make of people in their community. Through experience of the success and stability of these practices in commerce, acquaintances and strangers come to trust each other more generally. This creates a social environment where people willingly contribute to the public demands of justice and trust that those reasonable demands will also be met by others. Smith provides evidence for this extension of probity in private life to just conduct in public life in city and cantonal governments that relied on the selfassessed tax liabilities of merchants to pay for public goods. In those cases, 'every one is said to declare with the greatest frankness what he is worth, in order to be taxed accordingly' (Smith 1981 V.ii.f.11). Although individual transactions will often take place between people in unequal economic positions, the process of engagement encourages citizens to cultivate egalitarian norms of reciprocity, trust and respect that can be applied to the public sphere (Schwarze and Scott 2019, 77).

\section{Why thick economic liberties?}

I have argued that participation in commerce can make a unique contribution to the development of one's sense of justice. The standard Rawlsian framework includes rights as consumers of goods and choice of occupation as part of the basic liberties. The freedom to choose what to buy and where to work from a variety of workplaces under a market socialist system could offer precisely the sort of opportunities for cooperative encounters with a diverse 
set of people. By contrast, my account supports thick liberties to possess, build, buy and sell commodities and means of production, to negotiate contacts, and form and enter partnerships. These liberties also include the ability for individuals and associations to establish firms with the capacity to draw on external investment and establish distinctions between proprietors and workers. Must citizens in a liberal society have access to these rights as a matter of fundamental priority?

My case is that the ability to engage in private enterprise enhances the scale and scope of cooperation in a way that is ultimately necessary for the development of a widespread sense of justice within a political community. This is not a claim that it is impossible for an individual to develop a sense of justice when denied those liberties, nor that everyone individually in a society must have business experience to develop a sense of justice. Rather it is a claim that the additional liberty to engage in business makes a set of basic liberties fully adequate to the extent that we can expect the typical citizen to gain a sense of justice appropriate for a liberal society. It gives everyone the opportunity at least to observe voluntary cooperation across a community in a wide variety of settings and recognize that they are a part of it and benefit from it.

In a similar way, citizens do not all have to exercise the full range of political liberties that Rawls $(1999,197)$ argues to be basic, such as running for public office, to develop their moral powers adequately. Being immersed in political participation is not a part of many reasonable life plans. However, citizens need real opportunities to observe each other freely participating in political processes and to know they have equal liberties to enter that site in a more engaged way should they choose. Commerce must be included in these protected sites as well because it has a characteristic that one does not find in any other sites of moral cultivation in civil society: it obliges people with diverse backgrounds to interact and cooperate repeatedly in 
ways that require the cultivation of mutual trust. This is at the foundation of a society based on reasonable pluralism. In the rest of this section, I explain how commercial institutions make that distinctive contribution in way that socialist institutions cannot do in isolation and, in addition, enable economic cooperation in the public sector to take on the form of voluntary cooperation as well.

\section{The coordination of separate interests}

At the core of commercial society lies the division of labor: the greater specialization of individual contributions into ever more complex production processes. Smith uses his famous pin factory example to show how breaking a production process down into steps and having workers coordinate dramatically increases productivity (Smith 1981 I.i.3). However, Smith’s intent was not to show the efficiencies of the factory system as such, but rather to show the division of labor in a setting where it could be easily apprehended. To show how much wider the scale of cooperation on this same basis is, Smith discusses the example of the production of woolen coats: how they are transformed from raw material to finished products through various stages across a commercial society (Smith 1981 I.i.11). Whereas a pin factory can operate under the management of a single proprietor, the longer supply chains, to which intermediate goods like pins are contributors, have no overarching controller. Instead, production is driven by the various demands that consumers make in trying to live their lives and attempts by producers to fulfill those demands in the best ways they can in pursuit of profit and their other chosen ends. Because of the sheer scale of cooperation, most participants are somewhat indifferent to the other various contributors and the resulting product. You cannot rely on goodwill shared among all the contributors for the whole venture to succeed. As Smith (1981 I.ii.2) famously claims, 'It is not from the benevolence of the butcher, the brewer, or the baker, that we expect our dinner, but 
from their regard to their own interest.' Consider an everyday example of a finished product reliant on many intermediate stages that is familiar to scholars. An author might proudly display a new publication, but it is unlikely they will feel a close affinity with the bookbinder. The binder has probably not read the book and is somewhat indifferent as to its content, although they may take satisfaction seeing the physical work in good condition. The publisher cannot feel a close affinity to every seller that stocks their books. Some people in this venture find the enterprise personally valuable although for slightly different reasons. For example, a publisher might be in the trade precisely with the inspiring aim of bringing high-quality literature to the public. But a multitude of other contributors, from the copyeditor, the logger, the papermaker, the printer, to the delivery driver and the security guard at the distribution center probably do not. For them, the work is satisfactory, but it is pay that motivates them. Nevertheless, their contribution to the whole enterprise is essential.

Paid compensation plays an important role in tying complex ventures like these together. What payment does is allow people to contribute to a venture that they are not personally committed to, and then take the benefits received from their contribution to spend on goods that they value as part of achieving their life plans. It allows diverse plans, both economic and personal, to coordinate in ways that are otherwise impossible. It is the nexus that joins very separate kinds of lives together in ongoing cooperation. People can draw on the value of all the various specialized knowledge that others have cultivated when engaging in their own ventures. Moreover, people can contribute with confidence that their individual dealings established within the chain of cooperation is contributing to the production of goods that others (who they will probably never meet) find valuable. They get to link their relatively self-interested bargaining with a fair contribution to social welfare. As Smith (1981 I.ii.5) explains: 'Among men... the 
most dissimilar geniuses are of use to one another; the different produces of their respective talents, by the general disposition to truck, barter, and exchange, being brought... into a common stock, where every man may purchase whatever part of the produce of other men's talents he has occasion for.'

\section{Reconciling risk, liability and responsibility}

A second important feature of these complex chains of cooperation is the ability to allocate and diversify risk. This allows for much wider cooperation among people who disagree on the underlying expediency of a venture. A book is stocked in a bookstore in the hope, though certainly not the strong expectation, that it will find an interested reader who will buy it. Inevitably many copies will not find homes. Some will be returned and sold at a discount through alternative supply chains. Many will be pulped and turned into other paper goods. Yet few of the people involved in bringing the book to market can share in the financial risk. They require payment regardless of the actual realized gains of cooperation. Although authors might be willing to risk their time writing in aid of the uncertain venture of a new book, they are rarely willing or able to risk their own money on a publication run and advertising. The bookstores and distributors will not stock the book without a guarantee of a refund from the publisher. So it is usually going to be a publisher, and shareholders in the case of large publishers, who are willing to absorb the financial risk of a new publication. Through specializing in owning rights to publish a range of books, the publishing firm can reduce their overall risk for each publication that fails. Ultimately, it allows them to market a broad range of books and still survive because only a few need to be profitable. Private investment helps to dramatically expand the scope of mutual beneficial cooperation than would otherwise be available. 
Inevitably, most goods in complex supply chains are produced without a specific consumer in mind. Yet, if people were unwilling or unable to risk personal investment in the enterprise, then this form of cooperation would be impossible at this scale. It is not just the finding of a consumer that presents risk and uncertainty. It is the successful implementation of any step of production. When the viability of a supply chain is at stake, an individual worker cannot be held jointly liable for a failure in their associated enterprise that may be due to equipment failure, accident or someone else's mistake, even if that failure vitiates their personal contribution. It is this division of responsibility and risk that thick economic liberties permit because it allows individuals to develop, own, sell and invest in commodities and means of production that they are personally confident that they can use to contribute to other people's productive endeavors. If they turn out to be wrong, they absorb the cost rather than the other parties. This is what expands the scope of possible voluntary agreements. It is through ownership and investment that people take on liabilities for the successes and failures of the activities of others.

These 'thick' economic liberties expand possible forms of cooperation and interaction that contribute to the development a sense of justice. A feature of reasonable pluralism is that people will have different beliefs about what is a worthwhile enterprise, both practically in terms of fulfilling consumer desires and what they find interesting or valuable for pursuing their own personal commitments. They will have diverse beliefs about what sort of ventures are worth risking their own time and resources. The ability to compensate people as traders, workers or contractors, rather than joint owners in an enterprise, allows people to set aside these sources of disagreement. It allows the party more personally committed and identified with the venture to take on additional risk and responsibility. In other words, they are willing to agree on the relative 
distribution of costs, benefits and risks despite disagreement about the ultimate value of the shared enterprise. This experience of bargaining in the shadow of both practical and value disagreement lies at the core of developing a sense of justice for coping with reasonable disagreement in public settings.

In making these claims, it is not my intention to idealize the realm of commercial enterprise established through thick economic liberties. The relationships and experiences of cooperation only work as I have described if people approach these interactions with reasonable ethical constraints and if markets are competitive (Otteson 2019). Without well-functioning labor markets bolstered by an underlying social insurance scheme, people's experience of market society will be one of precarity and disempowerment (Baderin and Barnes 2018).

Competitiveness between firms is important because it is what raises workers to the same status as employers - making them each need each other reciprocally. These conditions create the choice environment where mutually beneficial agreements on the small-scale tend to lead to social benefits at the societal level.

One could give a parallel account of how moral powers are cultivated (along different dimensions) in sites likes families, churches, sports clubs and the democratic political process while still recognizing that abuse and exploitation can take place in these sites as well in nonideal settings. In non-ideal settings, for example, where people do not consistently comply with legitimate public rules, it is not possible for a society to aim to respect all basic liberties, and so economic liberty could not be prioritized in the way that I am proposing for more congenial scenarios here.

Why not a liberal or market socialism?

An important objection is that there are substitutes to private enterprise that can play the role of facilitating mutual economic cooperation across society. Scholars offer several alternative 
regimes associated with Rawlsian principles, including market socialism, workplace democracy and worker cooperatives (Hsieh 2005; Carens 1981; Roemer 1994; Cohen and Rogers 1994).

To answer this objection, it is necessary to recognize where the controversy lies between commercial liberty and socialist alternatives. Commercial liberalism requires only that private businesses be permitted, not that they should be pervasive or advantaged over other kinds of enterprise voluntarily constituted through people utilizing their basic liberties. For example, Switzerland is a liberal democratic society with a competitive market economy. Nevertheless, its largest retailer, Migros, is a consumer cooperative. A parallel example is the large employeeowned John Lewis Partnership in the liberal democratic United Kingdom (Lehmann 2014). Thus cooperatives and worker-owned firms are part of commercial societies and make an essential contribution to the chains of cooperation I have described in the previous section. The opportunity for people to work as freelancers, sole proprietors or co-owners of firms, rather than employees, is part of a commercial order. By contrast, socialist alternatives to commercial orders typically involve curtailing or prohibiting private enterprise and setting constraints on internal governance rules for firms rather than allowing them to emerge through private agreement.

With that in mind, the question is not one of picking between worker ownership and private ownership (as commercial societies include both), but rather what the consequences would be of prohibiting or substantially restricting the scope of private enterprise where it would otherwise emerge through contractual bargaining. On my account, it would substantially reduce the scope of voluntary cooperation in ways that would (1) reduce the diversity of interactions between cooperating participants and (2) make the overall market order less competitive because successful enterprises will no longer scale-up effectively to meet consumer demands and offer employment opportunities within the scheme of economic cooperation. 
Bringing in new workers to a cooperative or democratic workplace means accepting them as members or joint owners. They gain a share of control over the means of production that has been established and cultivated by the current membership based on shared risk and commitment to the venture. To preserve the firm in a form recognizable to its original members, they will have to ensure that new members have similar interests and attitudes to risk and responsibility. Otherwise, they may find the organization's business plan dramatically altered in a way that the original members would not have agreed to commit part of their lives if this had been understood at outset. This is a particularly fraught issue when dealing with cooperation across the generations. People will have different risk attitudes at different points in their lives and also different desires about how long to stay with a particular enterprise. Absent capital markets, the ability of owners to trade out of membership will be limited so they cannot voluntarily cede control of the organization to new owners in return for compensation. Without the ability for the current membership to exit through an exchange of shares in the organization, the key test of any new member of a cooperative enterprise will be whether they have similar preferences and talents to the current membership. The possibilities of close cooperation between people who have different values and interests will be dramatically reduced.

The other weakness is that without access to profit-seeking investors with exchangeable claims on firm equity, worker-owned firms tend to have much more limited incentive and capacity to grow when successful. Because scaling involves sharing profits on an equivalent basis with new entrants to the enterprise, the individual members will not personally benefit from the investment of scaling up the organization (Porter and Scully 1987). Although this is not a problem within a free commercial order where worker-owned firms adjust to the presence of commercial alternatives, if firms were exclusively constituted this way, it would mean that many 
opportunities to expand to meet consumers demands would be foregone, and employment opportunities in productive parts of the economy would be restricted. Many people would be excluded from productive participation in the economy because they are unable to a match to an existing firm that fits their attitude and profile. The connection between personal benefit and aggregate social benefits will have been attenuated. One solution would be to impute some inherent desire to pursue equality of opportunity as part of the motivation for these workerowners. But reliance on that sort of goodwill throughout an economy bears a closer resemblance to the patron-client relationships that predominate in pre-commercial orders rather than the kind of mutual exchange among equals that Smith affirms.

The areas of activity where cooperative partnerships tend to be established and persist in practice illustrate their limits in theory. Cooperatives in commercial orders classically include professional partnerships, such as law firms, where experienced workers contribute to common resources and operate under a single brand but work independently when dealing with clients. They can operate successfully in partnership because they each have homogenous interests as members of the same profession and are often at roughly the same career stage. Thus they are each willing to take on roughly the same level of risk, responsibility and shared costs and benefits of working in the same firm. They can operate as equals concerning themselves although they take great care when considering taking on a new partner. Another area is in retail firms, like supermarket chains, that have relatively simple scalable practices and routines, and do not require as many specialized workers or long-term capital investment (even then, there is often a reliance on internal federal structures to prevent capital being redistributed from one site to another). For other kinds of goods and services, especially innovative or capital-intensive firms, where risks and responsibilities cannot be shared among equal members, the capacity to raise 
private investment is critical.

The practical problem of getting people to cooperate across society without private enterprise is plausibly surmountable either through setting public rules that control membership entry or through having exclusively state-owned enterprises. The state could require successful firms to expand their scale and membership against the wishes of current members. This solution does not, however, substitute for what voluntary contracting and bargaining offers for developing a sense of justice. The key decisions about what constitutes a reasonable policy, as opposed to the administrative implementation of a given policy, are pre-empted by the political process. This denies most citizens the opportunity to make practical decisions that govern who they will deal with and how in ways that systematically produces aggregate social benefits. Yet this is precisely the experience citizens need for developing a sense of justice.

\section{Unions and the public sector}

What role is there for unions and public sector organization in a commercial order? These might appear to be alternative sites where a sense of justice could be cultivated. My answer parallels the role described above for cooperatives. They play a critical role in the ecology of commerce but cannot function as a complete replacement for private enterprise. Unions are an example of workers exercising their liberties of freedom of association and their thick economic liberties to create an organization that collectively bargains on their behalf. Workers' rights to self-organize through voluntary contracting are part of the basic economic liberties, and any commercial societies that lack those rights are unjust and incomplete. Within the broader scheme of cooperation, unions are essentially worker-owned firms that sell labor services to other firms. Just as entrepreneurs make use of economies of scale and the division of labor when forming firms, so can workers do the same through combination. Unions are, in addition, an important 
check against the private power that unrestrained employees can exert over workers (cf. Anderson 2019). Nevertheless, on my account, in order to ensure the persistence of the chains of cooperation that extend across society (as opposed to relations within industries or firms), unions and their members must contract with the various other kinds of firms that exist.

Similarly, we can observe many of the values underlying mutual cooperation in the activities of public organizations such as hospitals and schools. Thus, it may appear that an exclusively public-sector economy could function as effectively as a commercial order. On my account, the existence of a commercial order with which these organizations interact is critical for ensuring that they contribute to mutual cooperation. Public institutions make use of intermediate goods produced in the rest of the economy (including textbooks, computer equipment, medical devices and pharmaceuticals). Their ability to contribute to the social good is assured by their ability to draw on the resources and knowledge of the whole community which can only be done through voluntary bargaining when there is a substantial space for private markets. The existence of a diverse commercial society means that individuals are not reliant on a single employer (the state) for work. This disciplines public organizations so that they must offer at least competitive market wages and conditions. Unless effectively constrained by the same rules that apply to private firms, public enterprises can harm the communities they are meant to serve (Shleifer and Vishny 1997). So, commercial society helps to ensure that mutually beneficial arrangements are predominant in the public sector as well.

This challenges egalitarian liberal perspectives that associate economic justice with socialist economic institutions. A core feature of the Rawlsian enterprise is that society is a cooperative venture for mutual advantage. On my account, socialist institutions can bring about mutual benefits voluntarily at a small-scale (the equivalent of a village commune). However, 
they cannot ensure the benefits are to the interests of a whole political community; at least not without coercively administering people and resources in a way that will deny people experience of personally realizing mutual gains from negotiation and bargaining. To reconcile the meeting of social needs with procedural equality requires the addition of a market system for goods and services and competition between firms that have ability to develop their internal governance arrangements through voluntary contracting. While procedural equality is a necessary, not sufficient, condition for justice as a fairness, ultimately, the Smithian defense of commerce is supportive of social equality.

\section{Regulating basic liberties}

Attempts like mine to integrate basic economic liberties into a Rawlsian framework face the objection that they are ultimately offering an alternative justification for policies popular amongst $19^{\text {th }}$-century liberals but opposed to the principles of $20^{\text {th }}$ and $21^{\text {st }}$-century liberalism. Such a case is vulnerable to the criticism that there never was a 'natural' set of economic arrangements. All arrangements are the result of conflicts and compromises in each society. What sort of institutions are necessary to protect economic liberty has been subject to change throughout modern history. There is no paradigm to look back to, and if one does look back, one will see many illiberal processes and outcomes.

What my account requires, therefore, is a way of specifying a range of possible economic institutions compatible with treating economic liberty as basic. This is essential because, of course, we cannot expect economic liberties alone to produce a fair distribution of social resources. So space must be permitted for other institutions supporting the distribution of primary goods to play a role, including a welfare state potentially at least as expansive as that found in contemporary social democracies, or more radically a property-owning democracy 
(Platz 2016; Vallier 2015; 2019b). Highlighting the limited implications that Rawls draws from affirming basic liberties, in general, helps with this:

In understanding the priority of the basic liberties we must distinguish between their restriction and their regulation. The priority of these liberties is not infringed when they are merely regulated, as they must be, in order to be combined into one scheme as well as adapted to certain social conditions necessary for their enduring exercise. So long as what I shall call "the central range of application" of the basic liberties is provided for, the principles of justice are fulfilled (Rawls 2005, 295-96).

I suggest that protecting basic liberties corresponds to three procedural conditions that limit the way that basic liberties can be regulated. One condition refers to substantive aims of regulation, one to their priority, one to the form:

1. The principal aim of the regulation cannot be to reduce the ability of people to exercise a basic liberty, and the supposed aim cannot be merely speculative.

2. The public policy aim of the regulation must be to improve the exercise of the basic liberty regulated or another basic liberty (cf. Freiman and Thrasher 2019).

3. Any regulation of the exercise of a basic liberty must be implemented in a non-arbitrary way that applies to all on the basis of formal equality.

What this implies with respect to economic liberties is that there should be a substantial private economic sphere and that its regulation should be made on the principle of equality before the law. Thus a large range of institutional arrangements is compatible with protecting basic economic liberties, including social democracies with large public sectors and welfarestates (cf. Layman 2015). My account places priority on establishing a competitive market (cf. Rawls 2001b, 67). This may require regulations such as compulsory workmen's compensation, 
health and safety rules, vehicle insurance and licensing, consumer product labelling and financial disclosure, as well as antitrust enforcement to prevent private monopolies from emerging (a contemporary challenge posed by the new technology giants). As with other basic liberties, exactly how economic liberties are expressed and protected will depend on historical and cultural factors. Any such regulations cannot aim to restrict reasonable options that workers may voluntarily choose, and they must still leave significant opportunity for individuals and groups in civil society to negotiate their own terms of cooperation. Moreover, their substitution in the form of alternatives that reject individual economic liberties is ruled out.

\section{Applying basic economic liberties}

My argument is a contribution to the Rawlsian project of reconciling political philosophy with public understandings and underpinnings of liberal society, as well as empirical observations of the relationship between economic and political liberty (Lawson and Clark 2010). Economic liberty is one necessary but emphatically insufficient condition for a stable liberal society, which means that it cannot be granted priority above other basic liberties. So my account is not programmatic and has to be interpreted against the specific challenges of any given regime and community. Nevertheless, it is illustrative to ask what the implications my approach have for some practical issues over which classical and egalitarian liberals sometimes clash.

My approach does not rule out minimum wage laws because they can be framed in general terms. Instead, it places a public duty on those considering them to scrutinize the effect of regulation on the economic liberties of those participating in low-wage markets, especially those at risk of losing working hours or job opportunities if the wage is set too high. This calculus cannot be purely utilitarian. A minimum wage that successfully raises wages but at the 
cost of excluding even a small minority from employment would likely be unjust because of the particular limitation that exclusion from economic life has on a person's moral powers. The minimum wage cannot have a purely distributive intent behind it. It must be intended to remedy a plausible asymmetry of bargaining or information that prevents the low-wage market from working effectively. Alternative policies like employee and family tax credits, which do not directly interfere with freedom of contract and are usually more effective at achieving their stated distributive aims, may prove to be more conducive to ensuring everyone has access to their essential primary goods (Meyer and Wu 2018). Regulation and taxation of capital is similarly compatible with basic economic liberties when aiming to bring about distributive justice, to make markets transparent and competitive, as well as for collecting state revenue. However, regulations cannot be implemented with the simple intent of discouraging private ownership of capital or reducing investment activity as such.

Outside these issues of controversy, however, the protection of basic economic liberties are as likely to unite as to divide classical and egalitarian liberals on policy. Both, for example, may end up opposing policies such as occupational licensing or discriminatory zoning laws which are usually intended to reduce competition and have the effect of increasing living expenses for the disadvantaged (Lindsey and Teles 2017). A political process that permits arbitrary economic regulation can be captured by the powerful, undermining minority protections and generating social conflict (Berggren and Nilsson 2016). Appropriately specified economic liberties can protect the disadvantaged just as civil libertarian constraints on the regulation of civil society are generally to the advantage of the marginalized.

\section{Conclusion}


I argue for extending Rawlsian basic liberties to include a 'thick' set of economic liberties. It is based on the classical Smithian account of commerce as offering a site of moral improvement, especially in terms of trust and tolerance. This makes a necessary and unique contribution to citizens' reasonableness and a sense of justice appropriate for a liberal community. The contribution of economic liberty to experience of cooperation means that leaving it unprotected or giving it unequal protection would be unjust. However, affirming economic liberty as basic does not imply adherence to laissez-faire capitalism. Economic liberty is subject to weighting against other basic liberties, and must be subject to regulation to make it equally extensive to all, with the result that a range of institutions that value and prioritize economic liberty in different ways can nevertheless adequately respect it. Economic liberty cannot, however, be deliberately diminished to achieve some other social good or arbitrarily restricted. 


\section{References}

Anderson, Elizabeth. 2019. Private Government: How Employers Rule Our Lives (and Why We Don't Talk about It). Princeton, N.J: Princeton Univ. Press.

Baderin, Alice, and Lucy Barnes. 2018. "Risk and Self-Respect." British Journal of Political Science, October, 1-19. https://doi.org/10.1017/S0007123418000212.

Berggren, Niclas, and Therese Nilsson. 2016. "Tolerance in the United States: Does Economic Freedom Transform Racial, Religious, Political and Sexual Attitudes?" European Journal of Political Economy 45 (December): 53-70. https://doi.org/10.1016/j.ejpoleco.2016.06.001.

Bergh, Andreas. 2020. "Hayekian Welfare States: Explaining the Coexistence of Economic Freedom and Big Government." Journal of Institutional Economics 16 (1): 1-12. https://doi.org/10.1017/S1744137419000432.

Boettke, Peter J. 1997. "Where Did Economics Go Wrong? Modern Economics as Flight from Reality." Critical Review 11 (1): 11-64.

Brennan, Jason. 2019. "Against the Moral Powers Test of Basic Liberty." European Journal of Philosophy, November, ejop.12497. https://doi.org/10.1111/ejop.12497.

Carens, Joseph H. 1981. Equality, Moral Incentives, and the Market: An Essay in Utopian Politico-Economic Theory. Chicago: University of Chicago Press.

Cohen, Joshua, and Joel Rogers. 1994. "Solidarity, Democracy, Association." In Staat Und Verbände, edited by Wolfgang Streeck, 136-59. Wiesbaden: VS Verlag für Sozialwissenschaften. https://doi.org/10.1007/978-3-322-94220-3_5.

Daniels, Norman. 1979. "Wide Reflective Equilibrium and Theory Acceptance in Ethics." The Journal of Philosophy 76 (5): 256-82.

Debes, Remy. 2012. "Adam Smith on Dignity and Equality." British Journal for the History of Philosophy 20 (1): 109-40. https://doi.org/10.1080/09608788.2011.651315.

Flanigan, Jessica. 2018. "All Liberty Is Basic.” Res Publica 24 (4): 455-75. https://doi.org/10.1007/s11158-017-9368-z.

Freeman, Samuel. 2001. "Illiberal Libertarians: Why Libertarianism Is Not a Liberal View." Philosophy \& Public Affairs 30 (2): 105-51. https://doi.org/10.1111/j.10884963.2001.00105.x. . 2011. "CAPITALISM IN THE CLASSICAL AND HIGH LIBERAL TRADITIONS." Social Philosophy and Policy 28 (02): 19-55. https://doi.org/10.1017/S0265052510000208.

Freiman, Christopher, and John Thrasher. 2019. "The Right to Own the Means of Production." In Economic Liberties as Human Rights. Routledge.

Gaus, Gerald F. 2010. “Coercion, Ownership, and the Redistributive State: Justificatory Liberalism's Classical Tilt.” Social Philosophy and Policy 27 (01): 233. https://doi.org/10.1017/S0265052509990100.

Hardin, Russell. 2003. Liberalism, Constitutionalism, and Democracy. Oxford; New York: Oxford University Press.

Herzog, Lisa. 2014. "Adam Smith's Account of Justice Between Naturalness and Historicity." Journal of the History of Philosophy 52 (4): 703-26. https://doi.org/10.1353/hph.2014.0086.

Hirschman. 1982. "Rival Interpretations of Market Society: Civilizing, Destructive, or Feeble?" Journal of Economic Literature 20 (4): 1463-84. 
Hsieh, Nien-hê. 2005. "Rawlsian Justice and Workplace Republicanism." Social Theory and Practice 31 (1): 115-142.

Hume, David. 1994a. "Of Refinement in the Arts." In Hume: Political Essays, edited by Knud Haakonssen, 105-14. Cambridge Texts in the History of Political Thought. Cambridge: Cambridge University Press. https://doi.org/10.1017/CBO9781139170765.020. . 1994b. "Of the Jealousy of Trade." In Political Essays, edited by Knud Haakonssen, 150-53. Cambridge: Cambridge University Press. https://doi.org/10.1017/CBO9781139170765.

Kant, Immanuel. 1795. Perpetual Peace: A Philosophical Essay. Translated by M. Campbell Smith. London: George Allen \& Unwin.

Lawson, Robert A., and J.R. Clark. 2010. "Examining the Hayek-Friedman Hypothesis on Economic and Political Freedom." Journal of Economic Behavior \& Organization 74 (3): 230-39. https://doi.org/10.1016/j.jebo.2010.03.006.

Layman, Daniel M. 2015. "The Fair Value of Economic Liberty.” Res Publica 21 (4): 413-28. https://doi.org/10.1007/s11158-015-9301-2.

Lehmann, Matthias. 2014. "Cooperatives As Governance Mechanisms." European Company and Financial Law Review 11 (1). https://doi.org/10.1515/ecfr-2014-0031.

Levy, David M., and Sandra J. Peart. 2004. "Sympathy and Approbation in Hume and Smith: A Solution to the Other Rational Species Problem." Economics and Philosophy 20 (2): 331-49. https://doi.org/10.1017/S0266267104000239.

Lindsey, Brink, and Steven Michael Teles. 2017. The Captured Economy: How the Powerful Enrich Themselves, Slow down Growth, and Increase Inequality. New York, NY, United States of America: Oxford University Press.

McCloskey, Deirdre Nansen. 2007. The Bourgeois Virtues: Ethics for an Age of Commerce. Chicago: University of Chicago Press ;

- 2008. "Adam Smith, the Last of the Former Virtue Ethicists." History of Political Economy 40 (1): 43-71. https://doi.org/10.1215/00182702-2007-046.

- 2011. "A Kirznerian Economic History of the Modern World." Annual Proceedings of the Wealth and Well-Being of Nations 3 (2010-2011): 45-64.

Meyer, Bruce D., and Derek Wu. 2018. "The Poverty Reduction of Social Security and MeansTested Transfers." ILR Review 71 (5): 1106-53. https://doi.org/10.1177/0019793918790220.

Montesquieu, Charles Louis de Secondat. 1777. The Complete Works of M. De. Montesquieu. Vol. 2. 4 vols. London: T. Evans and W. Davis.

O’Neill, Martin. 2017. "Survey Article: Philosophy and Public Policy after Piketty: Survey Article: Philosophy and Public Policy after Piketty." Journal of Political Philosophy 25 (3): 343-75. https://doi.org/10.1111/jopp.12129.

Otteson, James R. 2019. Honorable Business: A Framework for Business in a Just and Humane Society. New York, NY: Oxford University Press.

Paganelli, Maria Pia. 2010. "The Moralizing Role of Distance in Adam Smith: The Theory of Moral Sentiments as Possible Praise of Commerce." History of Political Economy 42 (3): 425-41. https://doi.org/10.1215/00182702-2010-019. . 2017. "We Are Not the Center of the Universe: The Role of Astronomy in the Moral Defense of Commerce in Adam Smith." History of Political Economy 49 (3): 451-68. https://doi.org/10.1215/00182702-4193033. 
Platz, Jeppe Von. 2014. “Are Economic Liberties Basic Rights?” Politics, Philosophy \& Economics 13 (1): 23-44. https://doi.org/10.1177/1470594X13483466.

. 2016. "Social Cooperation and Basic Economic Rights: A Rawlsian Route to Social Democracy: Social Cooperation and Basic Economic Rights." Journal of Social Philosophy 47 (3): 288-308. https://doi.org/10.1111/josp.12153.

Porter, Philip K., and Gerald W. Scully. 1987. "Economic Efficiency in Cooperatives." The Journal of Law and Economics 30 (2): 489-512. https://doi.org/10.1086/467146.

Rawls, John. 1975. "Fairness to Goodness." The Philosophical Review 84 (4): 536. https://doi.org/10.2307/2183853.

. 1999. A Theory of Justice. Cambridge, Mass.: Belknap Press of Harvard University Press.

—. 2001a. "Distributive Justice." In Collected Papers, 130-53. Cambridge, Mass.: Harvard University Press.

- 2001b. Justice as Fairness: A Restatement. Cambridge, Mass: Harvard University Press. . 2005. Political Liberalism. Expanded ed. Columbia Classics in Philosophy. New York: Columbia University Press.

Rawls, John, and Philippe Van Parijs. 2003. "Three Letters on The Law of Peoples and the European Union." Revue de Philosophie Economique, no. 7: 7-20.

Roemer, John E. 1994. A Future for Socialism. Cambridge, Mass: Harvard University Press.

Samuelson, Paul A. 1978. "The Canonical Classical Model of Political Economy." Journal of Economic Literature 16 (4): 1415-1434.

Schliesser, Eric. 2017. Adam Smith: Systematic Philosopher and Public Thinker. New York, NY: Oxford University Press.

Schwarze, Michelle A., and John T. Scott. 2019. "Mutual Sympathy and the Moral Economy: Adam Smith Reviews Rousseau." The Journal of Politics 81 (1): 66-80. https://doi.org/10.1086/700003.

Shleifer, Andrei, and Robert W. Vishny. 1997. "A Survey of Corporate Governance." The Journal of Finance 52 (2): 737-83. https://doi.org/10.1111/j.1540-6261.1997.tb04820.x.

Smith, Adam. 1981. An Inquiry into the Nature and Causes of the Wealth of Nations. The Glasgow Edition of the Works and Correspondence of Adam Smith 2. Indianapolis: Liberty Classics.

- 1982. The Theory of Moral Sentiments. Edited by D. D. Raphael and A. L. Macfie. The Glasgow Edition of the Works and Correspondence of Adam Smith 1. Indianapolis: Liberty Classics.

Stilz, Anna. 2014. "Is The Free Market Fair?” Critical Review 26 (3-4): 423-38. https://doi.org/10.1080/08913811.2014.947746.

Sumner, Scott. 2015. "Ideological Differences in Economics: Why Is the Left-Right Divide Widening?” Econ Journal Watch 12 (1): 58-67.

Tomasi, John. 2012a. Free Market Fairness. Princeton: Princeton University Press.

—. 2012b. "Social Justice, Free Market Style." Public Policy Research 19 (1): 26-33. https://doi.org/10.1111/j.1744-540X.2012.00678.x.

Tribe, Keith. 2008. "Das Adam Smith Problem' and the Origins of Modern Smith Scholarship." History of European Ideas 34 (4): 514-25. https://doi.org/10.1016/j.histeuroideas.2008.02.001. 
Vallier, Kevin. 2015. “A Moral and Economic Critique of the New Property-Owning Democrats: On Behalf of a Rawlsian Welfare State.” Philosophical Studies 172 (2): 283-304. https://doi.org/10.1007/s11098-014-0303-2. 2019a. Must Politics Be War? Oxford: Oxford University Press. 2019b. "Rawls, Piketty, and the Critique of Welfare-State Capitalism." The Journal of Politics 81 (1): 142-52. https://doi.org/10.1086/700108.

Wolf, Brianne. 2017. "Beyond the Efficiency of the Market: Adam Smith on Sympathy and the Poor Law." In Interdisciplinary Studies of the Market Order: New Applications of Market Process Theory, edited by Peter J. Boettke, Christopher J. Coyne, and Virgil Henry Storr, 39-61. Lanham: Rowman \& Littlefield International. 